\section{The Universities and the Publication of the Results of Research in America.}

NE of the principal subjects dealt with by the Association of American Universities in their conference last November was the publication of the results of research. Scientific and learned periodicals are numerous in the United States, and there has until the present been but litile co-ordination. "The American Chemical Society," says the editor of the Yale Review, " now has under its management three journals : a monthly devoted to the theoretical aspects of the subject, another monthly devoted to industrial chemistry, and Chemical Abstracts, which reviews twice a month all publications carrying new contributions to chemistry in its various phases. The question of a similar consolidation has reached at least the stage of discussion in several other National Societies in order, not only to avoid duplication, but also to reduce overhead costs, and to bring together where it may be readily examined material that now lies hidden in hundreds of places and so may be easily overlooked." He suggests that universities might support periodicals published by such national societies in preference to establishing their own separate periodicals, and in particular, that instead of requiring dissertations for the doctor's degree to be published in extenso they should cause them to be " cut down to the bone " and the skeletons thus obtained to be given to the national societies for publication in their journals. The societies on their part might, he suggests, have their printing done by the University Presses.

An interesting sketch was given by the Director of the Wistar Institute for the Advancement of Biological Science of the operation since I908 of a "plan for assembling and publishing a number of national zoological journals under one central management." So successful has this proved that the combined annual sales of five journals has increased from I 4 Io to 5286 copies, while the income has been gradually overtaking the cost, notwithstanding a lavish distribution of free copies, notably 5000 dollars' worth to the principal libraries of Europea policy begun immediately after the armistice was signed and to be continued for five years.

The factors of success are thus summarised: a whole-hearted co-operation of the men of science interested, whether as author, editor, publisher, or reader, a centralised management looking ever to prompt publication and extensive distribution with efficiency and economy, concentration on a group of journals limited to one field of research, and guarantee both financial and scientific of an endowed institution devoted to the same field of science. A feature of the Institute's methods of publishing the results of research is the system of "Bibliographic Service Cards." These include the author's abstract as well as complete bibliographic references, and an announcement of the date when the complete article will appear. They are issued fortnightly to subscribers to all the Institute's journals, and extra copies are often distributed for advertising purposes.

\section{University and Educational Intelligence.}

MANCHESTER.-The Council of the University has appointed Dr. Robert Robinson to the chair of organic chemistry which was vacant owing to the appointment of Prof. A. Lapworth to the chair of chemistry. Prof. Robinson graduated at Manchester University in I905 with first-class honours in chemistry and was a graduate scholar and Le Blanc medallist. As research student, and later as a lecturer in organic chemistry in the University, a remarkable series of papers on natural plant products were produced in conjunction with Prof. W. H. Perkin and others. His synthetic work has also been singularly skilful. His work has been often concerned with the processes taking place in the living organism and has in many directions shown the way to development in biochemistry. In addition to his academic work, Prof. Robinson, as Director of Industrial Research to the British Dyestuffs Corporation, has gained experience of working conditions especially valuable to such an important centre of the dyestuff industry as Manchester. Prof. Robinson has previously held chairs of organic chemistry at Sydney and Liverpool, and the chair of chemistry at St. Andrews. He was elected a Fellow of the Royal Society in I920.

The Delegacy of the City and Guilds (Engineering) College has appointed Prof. C. L. Fortescue, of the Royal Naval College, Greenwich, to succeed Prof $T$. Mather, who is resigning the chair of electrical engineering in the College at the close of the present session.

THE Dr. Edith Pechey Phipson post-graduate scholarship of the London (Royal Free Hospital) School of Medicine will be awarded in June. It is open to all medical women, preferably coming from India, or going to work in India, for assistance in post-graduate study. It is of the annual value of Iool., for a term not exceeding three years. Applica tions for the scholarship must reach the Warden and Secretary of the School, 8 Hunter Street, W.C.I by May $3 \mathrm{I}$.

RECENT appointments to the staff of the Technical College, Bradford, include Mr. R. E. Stradling, as head of the department of civil engineering in the college, and Mr. H. J. B. Chapple, as lecturer in electrical engineering.

Applications are invited for the Ray-Lankester Investigatorship at the Marine Biological Laboratory, Plymouth. The post is of the value of rool. and is tenable for fifteen months, out of which the investigator will be required to devote five months at the laboratory to some subject of marine research. Applications should be addressed to the Director.

A CONFERENCE of representatives of the Universities of Great Britain and Ireland was held on Saturday last, May I3, at University College, London, under the presidency of Sir Donald MacAlister, vicechancellor and principal of the University of Glasgow. The discussion on advanced study and research was opened by Dr. J. C. Irvine, vice-chancellor and principal of the University of St. Andrews. Dr. Irvine expressed the opinion that research should be controlled in every university by a board or standing committee, with power to recommend changes in the teaching staffs of departments actively engaged in research, to allocate money voted for research purposes, and to consider such questions as travelling and publication grants.

Dr. L. R. Farnell, vice-chancellor of the University of Oxford, who opened the discussion on specialised study, stated that the idea of having one university for physical science and another for the humanities would be fatal to the cultivation of both branches of knowledge. On the other hand, it must be recognised that by reason of their surroundings, some universities were peculiarly fitted for certain studies. Mr. Fisher joined in this discussion, emphasising the growing need for co-operation between the universities, in respect of the distribution of studies according to the particular advantages of each. It was suggested that 
a committee of vice-chancellors should investigate claims for additional endowments by special departments and inquire whether the transference of trust funds to different subjects within the university was desirable or whether the migration of students requiring special subjects could be facilitated. Sir Henry Miers, vice-chancellor of Victoria University, Manchester, was emphatic on the point that higher education of the right type could be given only by universities or institutions of similar standing.

IF the number of suitable applicants is sufficient, the Board of Education will provide during the summer, courses of instruction of two weeks' duration for teathers of engineering science and electrical engineering in technical schools. The standard of the work will be that of the "National Certificates" in engineering of ordinary grade, but advanced treatment will be accorded to certain sections of the work. The courses will start on Saturday, July 22, and will end on Saturday, August 5. The courses will be held in Oxford, in the University Engineering Building, the University Electrical Laboratories, and in the new laboratories of the City of Oxford Technical School. The instruction in engineering science will be given by Prof. F. C. Lea, of Birmingham University, and that in electrical engineering by Prof. W. M. Thornton, of Armstrong College University of Durham, each of whom will have the assistance of a staff of tutors, lecturers and instructors. Teachers who wish to apply for permission to attend either course must fill up and return form $972 \mathrm{~T} /$ Engineering as soon as possible, so as to reach the Board's office not later than Monday, May 29.

Mr. J. W. Bispham, of the London County Council service (Technology Section), has been appointed principal of the Borough Polytechnic Institute, to fill the vacancy caused by the retirement of Principal C. T. Millis. He will take up his duties in September.

IN Bulletin No, 6, I92I, of the United States Bureau of Education, published for the guidance of students in other countries contemplating advanced study or research in the U.S.A., particulars are given regarding the graduate schools of 28 universities, including, inter alia, admission requirements, periods of study for degrees, noteworthy facilities for particular lines of graduate study (equipment and research funds, library facilities, and facilities for publication of research results), expenses of tuition and board and lodging. The graduate school now usually co-ordinates into one administrative unit all the advanced teaching and all the facilities for original research provided by the university. To obtain a master's degree, one year (Yale and Johns Hopkinstwo years) of post-graduate study devoted, as a rule, to not more than three subjects, including one " major," is usually required, while for a doctor's degree the minimum period is usually three years. Most universities require the dissertation for the doctorate to be published. The requirements for the Ph.D. degree parallel closely those proposed by the German universities, but attempts have recently been made to insist on a somewhat longer scholarly preparation and a more substantial thesis. Each university generally awards to graduate and professional students a number of fellowships and scholarships carrying stipends ranging from Ioo to 600 dollars, the holders of which are sometimes required to do one to six hours' teaching weekly. Foreign students will usually find it necessary to spend at least a year in residence at an American university before qualifying for one of these grants. The enrolment in graduate courses in the United States increased from $434^{\circ}$ in 1893 to 16,470 in 1916 .

\section{Calendar of Industrial Pioneers.}

May I8, I747. Bernardo Zendrini died.-One of the most celebrated Italian hydraulic engineers of the eighteenth century, Zendrini was also a mathematician and was one of the first to apply the infinitesimal calculus to practical problems. As mathematician and engineer to Ferrara, Modena and Venice he carried out many works connected with the rivers and ports of north-east Italy.

May I9, I907. Sir Benjamin Baker died.-Born in $x 840$, Baker was apprenticed at the Neath Abbey Iron Works in South Wales, and after gaining experience as a civil engineer became an assistant to Sir John Fowler, with whom he was afterwards in partnership. Among the great works he was associated with were the Forth Bridge, the Assouan Dam, the Central London Railway, and the Avonmouth Docks. As one of the leading engineers of his day he served on the Ordnance Committee, the Engineering Standards Committee, was elected a fellow of the Royal Society, and in 1895 served as president of the Institution of Civil Engineers. A memorial window to his memory has been placed in the north aisle of Westminster Abbey.

May 21, 1826. Georg von Reichenbach died.A famous German mechanician and instrument maker, Reichenbach was born in 1772 at Durlach. In his youth he spent some time at Boulton and Watt's works at Birmingham, and after his return to Germany was employed with his father in the manufacture of munitions. In I 800 he invented a dividing machine; the transit circle was re-introduced by him, and he collaborated with Utzschneider, Fraunhofer, and Ertel.

May 22, 1900. William Lindley died.-Trained as a civil engineer under Francis Giles, Lindley worked under Brunel on the Thames Tunnel, and in 1838 became engineer of the Hamburg and Bergedorf railway. He was afterwards responsible for the sewage works, the water works, and many of the engineering schemes which turned Hamburg into one of the greatest modern seaports.

May 23, 1800. Henry Cort died.-The inventor of the important process of puddling and also of the grooved rolls for manufacturing wrought iron, Cort, between 1765 and $\mathbf{1} 775$, made a fortune as a navy agent in Surrey Street, the Strand. Stimulated by the dearness of Russian iron, he then made experiments on iron-making and had works at Fareham and Gosport where, in $I 783$, he brought out his great inventions, but at the same time reduced himself to poverty. His inventions added enormously to the wealth of the country, and the puddling process supplied all the malleable iron for our engines, railways, and iron ships till the introduction of the Bessemer process of making mild steel.

May 23, I915. Pierre Emile Martin died.-A native of Bourges, and born in 1824, Martin in the early 'sixties began experimenting on the manufacture of steel in a small Siemens regenerative furnace, and in July 1865 took out his patent for the process in which pig-iron, scrap steel, and iron oxide are melted together on an open hearth. Till the introduction of the basiclined furnace of Thomas and Gilchrist, the Martin-or Siemens-Martin process, as it is known in Englandmade little headway against the Bessemer process. By I9I3, however, of 74 million tons of steel produced only 30 millions were produced in Bessemer converters and the remainder by the Martin process. Martin reaped no pecuniary advantage from his work, but in I9ro a fund was raised for him, and a few weeks before his death he was awarded the Bessemer medal.

E. C. S. 